\title{
EXPERIENCE OF DIAGNOSIS DISCLOSURE FOR TEENAGERS WITH HIV ${ }^{1}$
}

\author{
Crhis Netto de Brum², Cristiane Cardoso de Paula3, Stela Maris de Mello Padoin ${ }^{4}$,Samuel Spiegelberg Zuge
}

\begin{abstract}
${ }^{1}$ Study taken from the thesis - Being-an-adolescent-who-experienced-the-revelation-of-the-seropositive-diagnosis-for-HIV/AIDS: contributions to nursing and health care, presented to the Graduate Nursing Program, Universidade Federal de Santa Maria (UFSM), funded by the Programa de Apoio a Planos de Reestruturação e Expansão das Universidades Federais (REUNI), in 2013.

${ }^{2}$ Doctoral student. Graduate Nursing Program, Universidade Federal do Rio Grande do Sul. Professor, Undergraduate Nursing Program, Universidade Federal da Fronteira Sul. Chapecó, Santa Catarina, Brazil. E-mail: crhis.brum@uffs.edu.br

${ }^{3}$ Ph.D. in Nursing. Professor, Nursing Department, UFSM. Santa Maria, Rio Grande do Sul, Brazil. E-mail: cris_depaula1@ hotmail.com

${ }^{4}$ Ph.D. in Nursing. Professor, Nursing Department, UFSM. Santa Maria, Rio Grande do Sul, Brazil. E-mail: stelamaris_padoin@ hotmail.com

${ }^{5}$ Doctoral student, Graduate Nursing Program, UFSM. Santa Maria, Rio Grande do Sul, Brazil. E-mail: samuelzuge@gmail.com
\end{abstract}

\begin{abstract}
Phenomenological study with the objective of understanding the existential movement of teenagers in their experience of the disclosure of the human immunodeficiency virus diagnosis. The field research was undertaken at a university hospital in the South of Brazil, including phenomenological interviews with 12 teenagers. The analysis was based on Martin Heidegger's reference framework. The results appointed that the teenagers showed they have rules and limits for having something that the others do not have and accept taking their medication. They keep busy with their treatment due to family members' dominant solicitude. Over time, they learn to take care of themselves. By understanding the reasons for the treatment, based on the liberating request of their relatives and/or health professionals, they are concerned with taking care of themselves. Professional actions need to contemplate the biological and subjective dimension, with a view to going beyond the prescription, in order to commit the teenagers to their care.
\end{abstract}

DESCRIPTORS: Nursing. Truth disclosure. Adolescent health. Acquired immunodeficiency syndrome. HIV.

\section{VIVÊNCIA DA REVELAÇÃO DO DIAGNÓSTICO PARA O ADOLESCENTE QUE TEM HIV}

RESUMO: Estudo fenomenológico com o objetivo de compreender o movimento existencial do adolescente no vivido da revelação do diagnóstico do vírus da imunodeficiência humana. A pesquisa de campo ocorreu em um hospital universitário do Sul do Brasil, com entrevista fenomenológica com 12 adolescentes. A análise foi realizada com base no referencial de Martin Heidegger. Os resultados apontaram que o adolescente mostrou que tem regras e limites por ter algo que os outros não têm e aceita tomar o remédio. Mantem-se ocupado com o tratamento devido à solicitude dominadora dos familiares. Com o tempo, aprende a se cuidar. Ao compreender os motivos do tratamento, a partir da solicitude libertadora dos familiares e/ ou dos profissionais de saúde, preocupa-se em se cuidar. As ações profissionais precisam contemplar a dimensão biológica e subjetiva, com o intuito de ir além da prescrição, para comprometer o adolescente com o cuidado de si. DESCRITORES: Enfermagem. Revelação da verdade. Saúde do adolescente. Síndrome da imunodeficiência adquirida. HIV.

\section{VIVENCIA DE LA REVELACIÓN DEL DIAGNÓSTICO DE VIH PARA EL ADOLESCENTE}

RESUMEN: Estudio fenomenológico que objetivó comprender el movimiento existencial del adolescente con relación a la revelación del diagnóstico del Virus de Inmunodeficiencia Humana. La investigación de campo se dio en un hospital universitario en el sur de Brasil, con entrevistas fenomenológicas con 12 adolescentes. El análisis fue realizado con base en el referencial de Martin Heidegger. Los resultados mostraron que el adolescente cuenta con normas y límites por el hecho de tener algo que los demás no tienen, complementariamente él se compromete a tomar el medicamento. Él se mantiene ocupado con el tratamiento por causa de la solicitud dominante de los miembros de la familia. Con el tiempo, él aprende a cuidarse. Al comprender los motivos del tratamiento, a partir de la solicitud liberadora de los miembros de los familiares y/o de los profesionales de la salud, se preocupa en cuidarse. Las acciones profesionales necesitan contemplar la dimensión biológica y subjetiva, con el propósito de ir más allá de la prescripción para comprometer al adolescente con el cuidado de sí mismo.

DESCRIPTORES: Enfermería. Revelación de la verdad. Salud del adolescente. Síndrome de inmunodeficiencia adquirida. VIH. 


\section{INTRODUCTION}

Adolescents with the human immunodeficiency virus (HIV) can be divided in two groups according to the category of exposure: teenagers who got infected through vertical transmission (mother-to-child); and teenagers who got infected through horizontal transmission (exposure to injectable drugs and unprotected sexual relationships). ${ }^{1-2}$

Independently on the routes, however, in both groups, the adolescent has special health needs, mainly concerning the compliance with the medication technology. This need results in specific care demands, which imply continuing monitoring at the health services. ${ }^{3}$ Despite prevailing biomedical issues in daily care, the adolescents also face challenges in the psychosocial sphere, such as treatment compliance, prejudice in social relationships and diagnosis disclosure. ${ }^{4}$

The American Academy of Pediatrics recommends that children and adolescents have a right to information on their diagnosis. ${ }^{5}$ The relatives and/or caregivers tend to postpone this moment, as they blame themselves for the vertical transmission, present fear about the death of relatives with HIV and prejudice. ${ }^{6}$ Studies indicate that this revelation should take place early, the mean age starting as from the age of nine years. ${ }^{7-8}$ Other studies appoint, however, that the diagnosis is disclosed in adolescence, at a mean age of 13 years. ${ }^{9-10}$

The revelation permits the discovery or the confirmation of the diagnosis by the adolescents who had lived under the pact of silence thus far. ${ }^{11-12}$ The secret affects the daily life, the entry in school, the onset of sexual life, the treatment compliance and particularly the development of care autonomy. Revealing the diagnosis involves not only the relatives and/or caregivers, but those who are part of daily care, such as the health professionals. ${ }^{13-14}$

Hence, the objective is to understand the adolescent's existential movement in view of the diagnostic disclosure experience of HIV.

In that context, the relevance is highlighted of using Heidegger's phenomenology, considering that other studies ${ }^{8-10,12-13}$ have appointed a biological dimension in the revelation of the diagnosis. This framework reveals the dimension of the singularity and subjectivity of the adolescent's experiences in daily life permeated by HIV.

\section{METHOD}

Qualitative, phenomenological research, consolidated based on Martin Heidegger's theoretical- methodological reference framework. ${ }^{15}$ Twelve adolescents participated, who complied with the following inclusion criteria: a) age range between 13 and 19 years, 11 months and 29 days; ${ }^{1}$ b) outpatient monitoring at the infectious disease services of the Hospital Universitário de Santa Maria (HUSM), Rio Grande do Sul, Brazil; c) knowing the diagnosis. And with the following exclusion criteria: a) impairment that made verbal expression difficult; b) institutionalization (adolescent in situation of imprisonment). The number of subjects was not determined in advance, as the field stage, developed at the same time as the analysis stage, showed the end moment, when the meanings expressed in the interviews had already answered the research objective. ${ }^{16-17}$ Therefore, the field and analysis phases were developed simultaneously.

The data were produced between November 2011 and February 2012, after receiving approval from the Ethics Committee at Universidade Federal de Santa Maria, under CAAE 0321.0.243.000-11. The ethical premises of Resolution 196/1996 were complied with, in force at the time of the research. The adolescents' relatives and/or caregivers signed the Free and Informed Consent; 11 adolescents signed their participation through the Free and Informed Assent and one signed the Free and Informed Consent.

The field stage consisted of two moments: the phenomenological interview and collection from the patient file to develop the patient history. ${ }^{18-19}$

The phenomenological interview is a movement to understand the experience of the human being as manifested in his daily life. In that sense, it is appropriate to suspend the factual understanding of what was already known about the fact, with a view to moving towards the existential understanding of the adolescent. The interview was mediated by empathy and intersubjectivity, established between the adolescent and the researcher, based on the reduction of premises. The following guiding question was asked: what was it like for you to find out your diagnosis? As for the naming of the adolescent's serology, the way he mentioned or remained silent about his disease was respected, referred to as this, thing, this disease and virus.

Attention was needed to the discourse modes the adolescent manifested, such as: the gestures, pauses, silences, looks, among others. This movement permitted apprehending what was said and not said, determining respect for the adolescent's time and space. Thus, relevant adaptations were possible in the conduction of the interview in order to proceed with the meetings. 
To understand and deepen the meanings expressed in the adolescent's discourse, which is permeated by slang, empathetic questions had to be formulated based on the words the adolescents themselves expressed.

The discourse was audio recorded and described immediately after each interview, in line with the adolescent's original words. The interviews were coded using the letter A for adolescent, followed by Arabic numerals from 1 to 12 .

To collect information in the files, a script was used that considered the following items: sex; age; category of exposure to HIV; antiretroviral treatment; family constitution; life in support house; when he discovered the diagnosis, who revealed it. Based on that information, the adolescent's history could be developed, which serves to present the history, that is, the who of the adolescent with $\mathrm{HIV} /$ aids.

The analysis was developed based on two methodic moments, based on Heidegger's framework: ${ }^{15}$ comprehensive analysis and interpretive analysis. The comprehensive analysis, also called vague and median understanding, aims to understand the meanings the subjects attribute to their experiences focused on the research object. Therefore, the adolescents' testimonies were subject to attentive listening and readings, with a view to highlighting the essential structures. No categories imposed by background knowledge were used, which required the reduction of the researcher's premises. These structures composed an analytic picture, after which the units of meaning could be established.

The interpretative understanding, also called hermeneutics, was outlined based on the units of meaning. They unveiled the meanings, which were interpreted in the light of Martin Heidegger's framework. ${ }^{15}$

After the comprehensive analysis, which serves to discuss the adolescent's ontic dimension (the facts, that is, what is there, and therefore refers to the research subject as "adolescent"), Heidegger's second moment takes place. This, also known as interpretative understanding, takes place through the unveiling of the meanings of the being, when the adolescent is called the adolescent-being. This second moment serves to present the ontological dimension of the being (which is characterized by what was hidden and which, based on the analysis, end up being clarified by the meanings expressed in the framework). Hence, based on the two methodic moments, i.e. the analysis of the ontic dimension and the analysis of the ontological dimension, Hei- degger's existential movement is defined, which is centered on the subjects' discourse. In this study, it moved from the adolescent (ontic, marked by the established fact) to the adolescent-being (ontological, marked by the meanings).

Thus, it should be highlighted that the intent of the ontological dimension is to understand the sense of the being, without being occupied or concerned with ideas, concepts and opinions deriving from scientific knowledge. Nevertheless, that dimension intends to discuss the meanings through the understanding the being himself defines as the truth, which in this study rests on the premises of the author underlying the theoretical framework.

\section{RESULTS}

The comprehensive analysis constituted the following units of meaning: adolescent-being who experienced the disclosure of the HIV-positive diagnosis means: 1 ) having rules and limits due to having something the others do not have; and 2) accepting to take the medicine and, over time, getting accustomed and learning to take care of oneself.

The adolescents know that they need to follow rules on how to do the treatment, take the medicines, not miss the consults, undergo tests and talk to the health professionals because, when they get ill, they need to get hospitalized. They understand that they cannot get vaccinated and how they should act if they get hurt. In addition, they have to study.

They announce that they have limits. They know that their immunity is low and they can get ill. When they sleep elsewhere, they have to take their medication, which they find bad, as their colleagues do not do so. They want to use the computer until later and go to parties, but they cannot due to the medication time. They cannot consume alcoholic beverage, as it can interfere in the effect of the medicines. They manifest the desire to have a sexual relationship, girl/boyfriend and children, but are in doubt as to whether they will be able to. They did not want commitment and limits. They would like to be like the other adolescents without the disease.

I accept to take the medicines, come here [at the hospital] almost every month, do the tests, not being able to cut myself, I have to clean it, wash, I cannot let anyone touch my blood (A2).

[...] we want to go out, but we can't [...]. It changed! [...] I used to stay on the street, I didn't need to get home in time to take the medicine. [...] I cannot drink, I cannot do anything, I have to take care with the time. I used to drink before knowing the diagnosis (A3). 
Because there are the limits too. [...] there are rules for everything, you cannot go to the party, you cannot drink alcohol [...]. I have to get up and take the medicine [...] sometimes I go out and I need to watch the time [...] I stay on the computer. [...] I always had to take the medicines (A4).

[...] I had to do the treatment, I couldn't miss any consult [...] Anything we catch we have to go to hospital, be hospitalized, doctor all the time and injection, then it's difficult [silence]. [...] I go to the physician to see how things are, I go for the test, to see if everything is normal, if it's not I continue until I get cured [...]. I don't know, so I had to accept everything all organized [...] go out at night, I always have to get back early. For the next day to take the medicine at the right time (A5).

I know about the treatment I have to do. I have to do everything correctly to try and lead a normal life. Without being in hospital. I cannot take the vaccines [...] (A6).

I wanted to have a child. For now I cannot have a child. Because of the disease (A7).

[...] nothing so far [makes a gesture of sexual intercourse] just dating [because there is the disease] [...] (A8).

[...] you go out with the guys and at a certain time you have to take the medication, so you're already mistrusting about being late [...] you need to assume a commitment, know that there are limits for things (A10).

[...] if I sleep over at a friend's house, I have to take the medicine. And that's bad, because if they go there to my home they don't need to take anything (A11).

The adolescents mention that they do not like to take the medicines, even if the relative gives it. Sometimes, they hide from the relative that they do not take it, also because they feel nausea and dizziness. It's when the family and/or the health professionals explain that taking the medicines will improve their health, they feel the need to comply with the medication. They know that doing the treatment depends on themselves. They report that they are already accustomed to it, because they always need to take it. They know situations in which others did not accept the treatment, got ill and sometimes died.

[The mother] explained that it was for my health, [...] it was for me to take everything correctly that everything would be fine [...] I didn't like to take it, I wanted to throw up, felt dizzy [...] I was in hospital, then I started taking it (A1).

[...] It's because she [the sister] didn't take care, she didn't accept what the doctors gave her [the sister died of the same disease] (A5).
[...] I take the medicines, treat myself. [...] [the physician said] I had to do the treatment correctly, that it would depend on me (A6).

[...] early in the morning it's my sister who gives it to me [the medicine] (A7).

Sometimes I take it normally, you know? [medicine] Without complaining, I actually feel good, but just when I want to [...] because I only know that mom used to give me medicine, so first she gave me and I put it in my mouth and everything, and I went to the room and spit everything through the window (A11).

The adolescents announce that they got scared by the diagnosis and the treatment; after they got accustomed, they understood that it would be better for their health. In that sense, they had to take the medicines, their health got better and they managed to take care of themselves. They know that they have to use a condom in sexual relationships for protection, as they can get ill when they get infected by other sexually transmissible diseases, and even transmit the virus to other people.

[...] it was good [take the medicines] because my health got better [...]. I got scared but I had to understand that it was for my health, for my own good [...] I still do not like it, but I am taking it [...] (A1).

[...] after the disclosure of this disease, I managed to take care of myself, take the medicines (A2).

When they told me about the diagnosis I had to do the treatment (A3).

If we don't treat it we may not get cured, if we don't take [the medicines] it may not work to get better (A4).

[...] now I got accustomed to using a condom [...] protect oneself (A7).

[...] you don't die of that anymore, if you take the medicine everything will be fine. Then I started coming to the doctor and treat myself [silence] (A8).

[...] I didn't think it was bad to take the medicine, because I knew it would help me to get better, it would help my immunity, help me to get well (A12).

\section{DISCUSSION}

The adolescent-being has rules, limits and commitments for having this disease. In that sense, he has no choices, which is determined by the facticity of having a disease that is incurable yet and needs a continuing and ongoing treatment. Thus, he reveals the characteristic of being cast into an event that grants him the condition of remaining in a given situation for having no choice. He is cast into what is determined and what cannot be avoided, ${ }^{15}$ that is, having HIV and doing the treatment. 
The adolescent-being is cast in the world, as he cannot decide on whether or not to have HIV. He has no choice on the infection, starting from birth, nor on the diagnosis, previously established due to the unprotected sexual relationship.

Based on the facticity, the adolescent-being remained stuck to what the relatives and/ore health professionals told him to do: take the medicines, comply with the times, go to the hospital, do the treatment and the tests. Hence, the adolescent-being shows to be occupied in his daily life, engaged in what has to be performed. The occupation is the way of being that designates the compliance with something. ${ }^{15}$

The daily occupations of our habits are known to the adolescents, who always repeat the same things. The rules and limits imposed on them determine what should be done and keep them busy. Therefore, their being in view of the world is essentially occupation. ${ }^{15}$

Thus, he complies with what is said and prescribed, doing so because the others say it should be like that and not because he understands and decides to act so, revealing that he remained stuck to the dominant substitutive solicitude. By putting themselves in the position of the adolescent-being in order to take care of him, the relatives and/or health professionals take the lead in what should be done, without granting him alternatives and decisions on their care. This solicitude refers to when one jumps over the other, when one takes care of the other and puts oneself in the position of taking care of the other. ${ }^{20}$ In that sense, the adolescent-being can turn into someone who is dominated and dependent, even if in an implicit or hidden manner.

Nevertheless, in the experience of the revelation of the HIV diagnosis, the adolescentbeing establishes a relation with the family member and, sometimes, with the health professional. In this relation, he demonstrated his fear and, with support, got accustomed to the limits and rules and learned to take care of himself. This experience happens based on the Being-with-the-other and Being-with-oneself.

The being-with demonstrates the relational nature of the human, as the world is always something shared with the others and living is always living with. ${ }^{15}$ Each day, the being assumes a relational attitude that influences the way he takes a stand towards the world and the others.

Based on the relation established between relatives and/or health professionals and the adolescent-being, the reasons were explained why he needs to take the medicines. This relation permitted an existential movement in which, initially, the adolescent-being complies with what other people determine, followed by an understanding of the reasons for taking care of himself.

Hence, when they only complied with what they were determined to do, the remained within the dominant substitutive solicitude; while the relation (being-with) concerned the liberating anticipatory solicitude, which belongs to authentic caring, that is, instead of jumping over the other, save him to make him transparent to himself and free, also to take care of himself. ${ }^{20}$

This solicitude allows the adolescent-being to be concerned with his health, when he understands that the medicines will benefit his health. The concern permits the relation with the people, by promoting a movement towards becoming free and open to his possibilities. ${ }^{15}$ Thus, the adolescentbeing focuses on himself and understands himself as a being with possibilities for self-care, conceiving that doing the treatment depends on him and that he feels well by doing so.

In this existential movement from occupation to concern, the adolescent-being reveals himself in the being-with the relatives and being-with the health professionals who, by developing liberating care, allow him to experience their daily life as a being with possibilities.

\section{FINAL CONSIDERATIONS}

In view of the facticity of having HIV, the adolescent-being demonstrated he was busy with having to maintain the treatment. Through the relatives' dominant solicitude, he maintained this treatment because they gave him the medicines. Based on the liberating solicitude, when the relatives and/or health professionals explained what the treatment means for his health, he is concerned with taking care of himself.

This facticity determined the compliance with antiretroviral treatment in their daily life. Therefore, attentive care to adolescents and their family is fundamental, based on a dialogical relationship that allows them to consider themselves as co-accountable for their care. This relation permits an existential movement from being cared-for-by others to a care-with, which grants autonomy for self-care, assuming a commitment to the treatment demands: medicines, consults and tests.

The relatives and health professionals, particularly the nursing professionals, need to respect the time, space, limits and possibility of each adolescentbeing in the course of his diagnostic disclosure 
movement. Monitoring is indicated before, during and after the actual revelation.

The nurse's actions need to be focused on the biological dimension as well as the existential dimension of health care, with a view to offering support in the movement from occupation to concern, encouraging the adolescent-being to acknowledge himself as co-accountable in care.

\section{REFERENCES}

1. Ministério da Saúde (BR), Programa Nacional de DST e Aids. Boletim Epidemiológico Aids/DST. [Internet] Brasília; 2013. [cited 2014 Oct 01]. Available from: http://www.aids.gov.br/sites/default/files/ anexos/publicacao/2013/55559/_p_boletim_2013_ internet_pdf_p_51315.pdf

2. Souza BB, Vasconcelos CC, Tenório DM, Lucena MGA, Holanda RLT. A Política de AIDS no Brasil: uma abordagem histórica. J Manag Prim Health Care [Internet]. 2010 [cited 2014 set 30]; 1(1):23-6. Available from: http://www.jmphc.com/ojs/index.php/01/ article/view/5/6

3. Paula CC, Padoin SMM. Cuidado de enfermagem ao adolescente com HIV/AIDS. Programa de Atualização em Enfermagem (PROENF). Saúde da Criança e do Adolescente. 2013; 7(4):9-49.

4. Ayres JRCM, Paiva V, França I, Gravato N, Lacerda R, Negra MD, Marques HH, Galano E, Lecussan P, Segurado $\mathrm{AC}$, Silva $\mathrm{MH}$. Vulnerability, human rights, and comprehensive health care needs of young people living with HIV/ AIDS. Am J Public Health 2006; 96(6):1001-6.

5. American Academy of Pediatrics Committee on Pediatrics AIDS. Disclosure of illness status to children and adolescents with HIV infection. Pediatrics. 1999; 103(1):164-6.

6. Butler AM, Williams PL, Howland LC, Storm D, Hutton N, Seage GR. Impact of disclosure of HIV infection on health-related quality of life among children and adolescents with HIV infection. Pediatrics [Internet]. 2009 [cited 2012 Nov 5]; 123(3):[11telas]. Available from: http://pediatrics.aappublications. org/content/123/3/935.full.pdf+html

7. Madiba S, Mokwena K. Profile and HIV diagnosis disclosure status of children enrolled in a pediatric antiretroviral program in Gauteng Province, South Africa. J Trop Med Public Health. 2013; 44(6):1010-20.

8. Abebe W, Teferra S. Disclosure of diagnosis by parents and caregivers to children infected with HIV: prevalence associated factors and perceived barriers in Addis Ababa, Ethiopia. AIDS Care. 2012; 24(9):1097-102.

9. Mawn BE. The changing horizons of U.S. families living with pediatric HIV. West J Nurs Res. 2012; 34(2):213-29.

10. Brown BJ, Oladokun RE, Osinusi K, Ochigbo S, Adewole IF, Kanki P. Disclosure of HIV status to infected children in a Nigerian HIV Care Programme. AIDS Care. 2011; 23(9):1053-8.

11. Ribeiro AC, Padoin SMM, Paula CC, Terra MG. The daily living of adolescents with HIV/AIDS: impersonality and tendency to fear. Texto Contexto Enferm [internet]. 2013 [cited 2015 Apr 21]; 22(3):[7 telas]. Available from: http://www.scielo.br/pdf/ tce/v22n3/v22n3a14.pdf

12. Guerra CPP, Seidl EMF. Crianças e adolescentes com HIV/Aids: revisão de estudos sobre revelação do diagnóstico, adesão e estigma. Paideia. 2009; 19(42):59-65.

13. Domek GJ. Debunking common barriers to pediatric HIV disclosure. J Trop Pediatr. 2010; 56(6):440-2.

14. Paula CC, Cabral IE, Souza IEO. O (não) dito da AIDS no cotidiano de transição da infância para adolescência. Rev Bras Enferm. 2011; 64(4):658-64.

15. Heidegger M. Ser e tempo. Petrópolis (RJ): Vozes; 2009.

16. Boemer MR. A condução de estudos segundo a metodologia de investigação fenomenológica. Rev Latino-am Enfermagem. 1994; 2(1):83-94.

17. Paula CC, Cabral IE, Souza IEO, Padoin SMM. Movimento analítico hermenêutico heideggeriano: possibilidade metodológica para a pesquisa em enfermagem. Acta Paul. Enferm [Internet]. 2012 [citedem 2013 Ago 22]; 25(6):984-9. Available from: http:/ / www.scielo. br/pdf/ape/v25n6/v25n6a25.pdf.

18. Carvalho AS. Metodologia da entrevista: uma abordagem fenomenológica. Rio de Janeiro (RJ): Agir; 1987.

19. Paula CC, Padoin SMM, Terra MG, Souza IEO, Cabral IE. Modos de condução da entrevista em pesquisa fenomenológica: relato de experiência. Rev Bras Enferm. [Internet]. 2014 [cited 2014 Oct 04]; 67(3):46872. Available from: http://www.scielo.br/pdf/ reben/v67n3/0034-7167-reben-67-03-0468.pdf

20. Heidegger M. Todos nós... Ninguém: um enfoque fenomenológico social. São Paulo (SP): Moraes; 1982. 